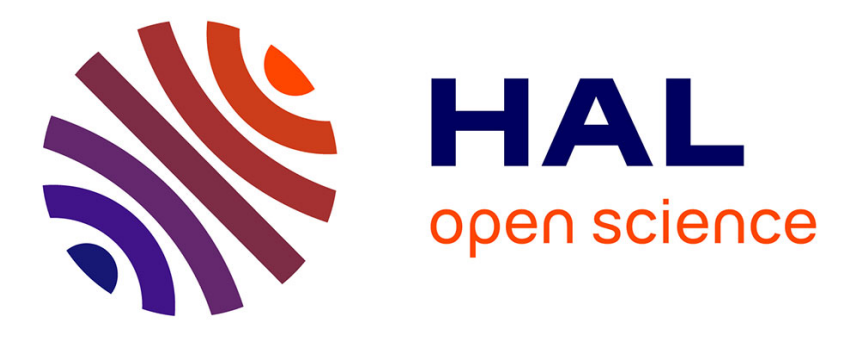

\title{
Preparation of non-racemic single-stereocentre a-aminonitriles and a study of their fate in Bruylants reactions.
}

Virginie Beaufort-Droal, Elisabeth Pereira, Vincent Thery, David J Aitken

\section{- To cite this version:}

Virginie Beaufort-Droal, Elisabeth Pereira, Vincent Thery, David J Aitken. Preparation of nonracemic single-stereocentre a-aminonitriles and a study of their fate in Bruylants reactions.. Tetrahedron, 2006, 62, pp.11948-11954. 10.1016/j.tet.2006.09.087 . hal-00118398

\section{HAL Id: hal-00118398 \\ https://hal.science/hal-00118398}

Submitted on 16 Feb 2007

HAL is a multi-disciplinary open access archive for the deposit and dissemination of scientific research documents, whether they are published or not. The documents may come from teaching and research institutions in France or abroad, or from public or private research centers.
L'archive ouverte pluridisciplinaire HAL, est destinée au dépôt et à la diffusion de documents scientifiques de niveau recherche, publiés ou non, émanant des établissements d'enseignement et de recherche français ou étrangers, des laboratoires publics ou privés. 


\title{
Preparation of non-racemic single-stereocentre $\alpha$-aminonitriles and a study of their fate in Bruylants reactions
}

\author{
Virginie Beaufort-Droal, Elisabeth Pereira, Vincent Théry and David J. Aitken* \\ Laboratoire SEESIB (UMR 6504-CNRS), Département de Chimie, Université Blaise Pascal-Clermont-Ferrand II, \\ 24 avenue des Landais, 63177 Aubière cedex, France
}

Received 7 August 2006; revised 16 September 2006; accepted 21 September 2006

Available online 25 October 2006

\begin{abstract}
A number of chiral carboxamide dehydration methods were investigated for the preparation of four representative enantiomerically enriched $\alpha$-aminonitriles possessing only one stereogenic centre; best results were observed using Burgess' salt (yield up to $87 \%$, er up to $92 / 8$ ) or the trifluoroacetic anhydride-triethylamine combination (yield up to $98 \%$, er up to $86 / 14$ ). Two of the aminonitriles thus obtained were subjected to Bruylants reactions with a methyl Grignard reagent to furnish the corresponding tertiary amines; these products, along with any unreacted starting materials, were obtained essentially in racemic form. In accord with the accepted mechanism for this reaction, a magnesium species is implicated in the formation of an iminium, the common intermediate for both chemical transformation and racemization processes.

(c) 2006 Elsevier Ltd. All rights reserved.
\end{abstract}

\section{Introduction}

The reaction of a Grignard reagent with an $N, N$-disubstituted $\alpha$-aminonitrile bearing at least one substituent at the $\alpha$-carbon to give an amine has been known for 80 years, and is generally known as the Bruylants reaction, after its discoverer. ${ }^{1,2}$ From the outset, it has always been assumed that the reaction proceeds by initial departure of cyanide to give an iminium intermediate, which then undergoes rapid addition of an organic nucleophile to give the substituted product (Scheme 1). This mechanism is perfectly reasonable, and consistent with a number of experimental observations, including (a) the cases in which the aminonitrile precursors possess nearby chiral centres, in which a high degree of diastereoselectivity is often achieved, ${ }^{2,3}$ and (b) modifications of the reaction in which an iminium is specifically generated from an aminonitrile by using a decyanating agent (such as a silver salt), and the Grignard nucleophile is added later in the

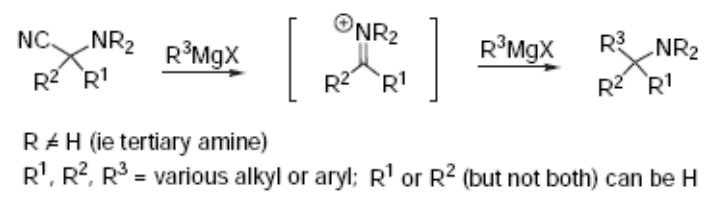

Scheme 1.

\footnotetext{
* Corresponding author. Tel.: +3347340 71 84; fax: +3347340 77 17; e-mail: david.aitken@univ-bpclermont.fr
}

reaction procedure. ${ }^{2 \mathrm{k}, 4}$ It is interesting to note that-perhaps in testimony of the success of the mechanistic proposal- no direct proof for the iminium intermediate in the Bruylants reaction has been either sought nor acquired.

Recently, we carried out a theoretical study of the reaction of a Grignard reagent with a particular aminonitrile system. ${ }^{5}$ One intriguing result which emerged from this study was the apparent plausibility of a reaction pathway leading formally to a Bruylants type substitution reaction. Initial formation of an $\mathrm{N} \rightarrow \mathrm{Mg}$ Lewis acid-base complex followed by intramolecular substitution of the nitrile group by the complexed alkyl group would give the substitution product (Scheme 2). This transformation appeared feasible on the basis of orbital interactions for the case study and was only slightly less favoured energetically than the experimentally observed addition reaction. While we at no point imagined disproving the intermediacy of an iminium in the Bruylants reaction, we felt that all previous studies or applications thereof had been contented with the fact that the results were compatible with this accepted mechanism; in other words, no detailed search for any evidence of an alternative mechanism, operating even to a minor extent, had been carried out.

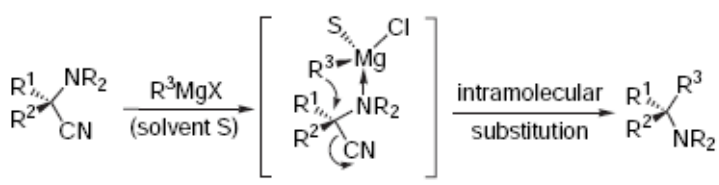

Scheme 2 . 
We wanted to devise some experiments specifically designed to bring to light any evidence at all concerning an intracomplex substitution mechanism, along the lines of that suggested in Scheme 2. This mechanism should proceed with inversion at the reactive $\alpha$-carbon centre, so that if the aminonitrile precursor is non-racemic, then the amine product should likewise be obtained in enantiomerically enriched form. In contrast, an iminium intermediate devoid of any chiral information should undergo nucleophilic attack with equal probability on either face of the planar reaction centre leading to racemic material. There is some precedent for a mechanistic investigation based on this rationale: reactions of $\mathrm{Me}_{2} \mathrm{CuLi}-\mathrm{BF}_{3} \cdot \mathrm{Et}_{2} \mathrm{O}$ with acetals in which the acetal carbon was the only stereogenic centre provided partially enantiomerically enriched ether products, showing that an $\mathrm{S}_{\mathrm{N}} 1$ process was operating simultaneously with an $\mathrm{S}_{\mathrm{N}} 2$ and/or ion pair mechanism. ${ }^{6}$

We therefore envisaged the examination of the stereochemical course of the Bruylants reactions of non-racemic $\alpha$-aminonitriles in which the reacting $\alpha$-carbon atom was the only stereogenic centre. This in turn presented us with the challenge of preparing appropriate chiral non-racemic substrates for these reactions, for which, surprisingly, almost no precedent existed.

\section{Results and discussion}

\subsection{Selection and preparation of starting materials}

The enantioselective preparation of single-stereocentre aminonitriles in which the amine lone pair is free is not a simple matter, since such compounds are expected to be configurationally labile. The literature is bereft of reports on the preparation of such $\mathrm{N}, \mathrm{N}$-dialkylated aminonitriles in enantiomerically enriched form. ${ }^{7}$ We are aware of only one such example, $(S)$-1-benzyl-2-cyanopiperidine, prepared in several steps from a non-racemic cyanohydrin. ${ }^{8}$ Related structures therefore drew our attention. $N$-Unsubstituted examples (i.e., derivatives of general formula $\mathrm{H}_{2} \mathrm{NCR}^{1} \mathrm{R}^{2} \mathrm{CN}$ ) can be obtained from racemates by resolution (usually with tartaric acid $)^{9,10}$ or through enantioselective enzymatic transformations. ${ }^{10,11}$ As expected, these materials are stable only as their hydrochlorides (or other salts). Several examples of such compounds have also been prepared from enantiomerically enriched cyanohydrins. ${ }^{12}$ Recently, catalytic enantioselective modifications of the Strecker reaction exploiting chiral catalysts have been developed successfully, ${ }^{13}$ but the products are invariably $\mathrm{N}$-monosubstituted $\alpha$-aminonitriles (general formula $\mathrm{R}^{3} \mathrm{NHCR}{ }^{1} \mathrm{R}^{2} \mathrm{CN}$, or their $\mathrm{N}$-acylated derivatives in some applications), since the precursors are preformed imines. ${ }^{14}$ Perhaps the most often used approach to obtain non-racemic $N$-monosubstituted aminonitriles is the dehydration of a derivative of the corresponding amino acid carboxamide. $\mathrm{POCl}_{3} /$ pyridine, ${ }^{15}$ tosyl chloride/pyridine, ${ }^{16}$ trifluoroacetic anhydride/triethylamine (TFAA/Et $\left.{ }_{3} \mathrm{~N}\right),{ }^{17}$ triflic anhydride/triethylamine,${ }^{18}$ dibutyltin oxide, ${ }^{19}$ a number of reagents used for peptide coupling, ${ }^{20}$ the cyanuric chloride/dimethylformamide (CyuCl/DMF) combination $^{21}$ and Burgess' salt ${ }^{22}$ have all been reported as successful dehydrating agents, although, somewhat frustratingly, the enantiomeric purities of the resulting aminonitriles are not always fully determined. More importantly, all of these cases involve amino acid carboxamide starting materials in which the amine nitrogen is protected in some way, usually as a carbamate or an amide, which leads to products of general structure PNHCR ${ }^{1} \mathrm{R}^{2} \mathrm{CN}$, where $\mathrm{P}$ is a protecting group. In one exception to this trend, a short series of amino acid carboxamides with free $\mathrm{NH}_{2}$ groups have been dehydrated with (2-pyridyl)sulfonyl chloride/DMF combination to give the amidine derivatives of the $\alpha$-aminonitriles; ee values were not reported. ${ }^{23,24}$

We decided to investigate $\alpha$-aminonitriles of type 1 . The aminonitrile with the aromatic $\alpha$-substituent (1a) was expected to be more prone to racemization and was investigated first. The appropriate tertiary amine carboxamide 3a was prepared from the readily available $25(R)$-phenylglycine carboxamide 2 a by reaction with 1,5-dibromopentane under basic conditions to construct the piperidine ring (Scheme 3).

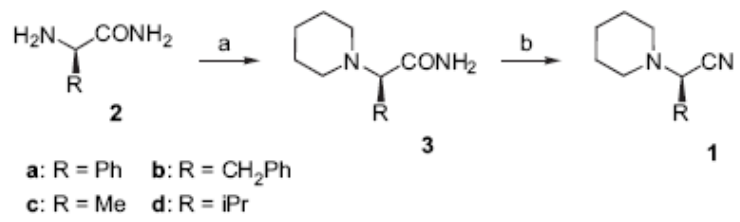

Scheme 3. For simplicity, only one stereochemical representation is presented here; the absolute configurations of the compounds were: $(R)-\mathbf{2 a}$ $(R)-\mathbf{2 b},(S)-\mathbf{2 c}$ and $(S)-2 \mathrm{~d}$. Reagents and conditions: (a) $\mathrm{Br}\left(\mathrm{CH}_{2}\right)_{5} \mathrm{Br}$, $\mathrm{K}_{2} \mathrm{CO}_{3}$, EtOH, reflux; $96 \%$ for $3 \mathrm{a}, 79 \%$ for $3 \mathbf{b}, 62 \%$ for $3 \mathbf{c}, 56 \%$ for $\mathbf{3 d}$; (b) dehydrating agent (see Tables 1 and 2 and text).

For the key dehydration step, most of the reagents reviewed above were examined. Enantiomeric ratios of the product were determined only in cases where the chemical yield and the optical rotation were considered encouraging. Results are presented in Table 1.

The configurational lability of the target aminonitrile was clearly in evidence. Four of the dehydrating agents tested furnished an extensively or totally racemized product, and were poor-to-moderate performers in terms of chemical yields. $\mathrm{CyuCl} / \mathrm{DMF}$ gave 1a with reasonable enantiomeric enrichment, although the isolated yield was moderate. A very good yield but slightly lower enantiomeric enrichment was achieved by using TFAA/Et ${ }_{3} \mathrm{~N}$; it was interesting to note that this reagent performed much better than $\mathrm{Tf}_{2} \mathrm{O} / \mathrm{Et}_{3} \mathrm{~N}$. Burgess' salt arguably gave the best results, in the combined terms of clean product, decent yield and useful enantiomeric

Table 1. Dehydration reactions of 3a to give 1a (see Scheme 3)

\begin{tabular}{llrl}
\hline Reagent & \multicolumn{3}{c}{ 3a $\rightarrow$ 1a } \\
\cline { 2 - 4 } & Yield $(\%)^{\mathrm{a}}$ & $\mathrm{OR}^{\mathrm{b}}$ & $\mathrm{er}^{\mathrm{c}}$ \\
\hline $\mathrm{POCl}_{3} / \mathrm{Py}$ & 30 & +10 & - \\
$n-\mathrm{Bu}_{2} \mathrm{SnO}$ & 36 & 0 & - \\
$\mathrm{TsCl} / \mathrm{Py}$ & 64 & 0 & - \\
$\mathrm{Tf}{ }_{2} \mathrm{O} / \mathrm{Et}{ }_{3} \mathrm{~N}$ & 62 & +3 & - \\
$\mathrm{CyuCl} / \mathrm{DMF}$ & 53 & +39 & $80 / 20$ \\
$\mathrm{TFAA} / \mathrm{Et}{ }_{3} \mathrm{~N}$ & 92 & +36 & $77 / 23$ \\
Burgess' salt & 78 & +44 & $92 / 8$ \\
\hline
\end{tabular}

a Yields are given for isolated (spectroscopically pure) material.

${ }^{\mathrm{b}}$ Optical rotations (OR) are given for $[\alpha]_{\mathrm{D}}^{2}\left(\mathrm{c} 1.0, \mathrm{CHCl}_{3}\right)$.

c Enantiomeric ratios (er) were determined as indicated in the text. 
enrichment. Even so, partial racemization seems unavoidable. Aminonitrile 1a could be chromatographed on a flash silica gel column with no detectable changes in enantiomeric enrichment; however, crystallization of 1a from methanol provoked complete racemization.

We then tested the three best methods of dehydration on the three other $\alpha$-aminonitriles $\mathbf{3 b}$-d. These compounds were prepared in an analogous fashion to $\mathbf{3 a}$, starting from the carboxamides of $(R)$-Phe, $(S)$-Ala and $(S)$-Val, respectively (Scheme 3). Results for the dehydration reactions are presented in Table 2. CyuCl/DMF performed poorly in terms of both chemical yield and enantiomeric enrichment. Burgess' salt and TFAA/Et ${ }_{3} \mathrm{~N}$ performed reasonably well; chemical yields were more variable with the latter, while enantiomeric ratios for the series of compounds 1 did not differ significantly. In all cases, partial racemization was still evident. Rather surprisingly, this was more the case with the methylbearing derivative $1 \mathbf{c}$, while the other aliphatic derivatives 1b and $1 d$ were not less racemized than the aromatic derivative 1a.

For this work, we required a method for the determination of the enantiomeric ratios. Several options were examined using authentic racemic materials $( \pm)-\mathbf{1 a}-\mathbf{d}$, which were prepared by standard Strecker condensation procedures. For $1 \mathrm{~b}$ and $1 \mathrm{c}$, a ${ }^{1} \mathrm{H}$ NMR technique was convenient: in $\mathrm{CDCl}_{3}$ solution, the presence of 7-8 equiv of the chiral resolving agent (S)-2,2,2-trifluoro-1-(9-anthryl)ethanol ${ }^{26}$ induced complete separation of the methine triplet signals in the spectrum of $( \pm)-1 \mathbf{b}$ and one of the piperidine $\mathrm{C} 2$ methylene signals in the spectrum of $( \pm)-1 \mathrm{c}$. This technique failed for 1d, so we used 1 equiv of $(R)$-Mosher's acid ${ }^{27}$ in $\mathrm{C}_{6} \mathrm{D}_{6}$ to effect the separation of the methine doublet signals in the ${ }^{1} \mathrm{H}$ NMR spectrum of $( \pm)-1 d$. None of the NMR techniques was suitable for the analysis of $1 \mathbf{a}$, so we resorted to the use of chiral HPLC, which gave good baseline enantiomer separation. It is noteworthy that we were unable to find a universally convenient analytical technique within this small series of related substances.

Table 2. Dehydration reactions of $\mathbf{3 a - d}$ to give 1a-d (see Scheme 3)

\begin{tabular}{|c|c|c|c|c|c|c|}
\hline \multirow[t]{2}{*}{ Reaction } & \multicolumn{2}{|c|}{$\mathrm{CyuCl} / \mathrm{DMF}$} & \multicolumn{2}{|c|}{ TFAA/ $/ \mathrm{Et}_{3} \mathrm{~N}$} & \multicolumn{2}{|c|}{ Burgess' salt } \\
\hline & Yield $(\%)^{\mathrm{a}}$ & $e^{b}$ & $\overline{\text { Yield }(\%)^{\mathrm{a}}}$ & $\mathrm{er}^{\mathrm{b}}$ & Yield $(\%)^{\mathrm{a}}$ & $\mathrm{er}^{\mathrm{b}}$ \\
\hline $3 a \rightarrow 1 a$ & 53 & $80 / 20$ & 92 & $77 / 23$ & 78 & $92 / 8$ \\
\hline $3 b \rightarrow 1 b$ & 45 & $73 / 27$ & 98 & $67 / 33$ & 71 & $77 / 23$ \\
\hline $3 c \rightarrow 1 c$ & 10 & $67 / 33$ & 44 & $60 / 40$ & 80 & $53 / 47$ \\
\hline $3 d \rightarrow 1 d$ & Degradation & - & 59 & $86 / 14$ & 87 & $81 / 19$ \\
\hline
\end{tabular}

a Yields are given for isolated (spectroscopically pure) materials.

${ }^{b}$ Enantiomeric ratios (er) were determined as indicated in the text.

\subsection{Bruylants reactions}

Enantiomerically enriched samples of $1 \mathbf{a}$ and $1 \mathbf{b}$ were treated with 2 equiv of methyl Grignard reagent under typical Bruylants conditions ( $\mathrm{Et}_{2} \mathrm{O}$ solution, $0^{\circ} \mathrm{C}$ to $\mathrm{rt}$, overnight). Following mild acidic aqueous work-up, the crude product mixture was analyzed; subsequent chromatography on silica gel permitted the isolation of the appropriate products (Scheme 4). Results are presented in Table 3.

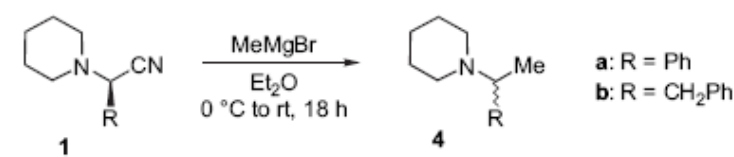

Scheme 4 .

Table 3. Bruylants reactions of $\mathbf{1 a , b}$ to give $\mathbf{4 a , b}$ (see Scheme 4)

\begin{tabular}{|c|c|c|c|c|c|c|}
\hline \multirow[t]{2}{*}{ Substrate } & \multirow[t]{2}{*}{$\mathrm{er}^{\mathrm{b}}$} & \multirow{2}{*}{$\begin{array}{l}\text { Equiv } \\
\text { MeMgBr }\end{array}$} & \multicolumn{2}{|c|}{ Recovered 1} & \multicolumn{2}{|c|}{ Product 4} \\
\hline & & & Yield $(\%)^{\mathrm{a}}$ & $\mathrm{er}^{\mathrm{b}}$ & Yield $(\%)^{\mathrm{a}}$ & $\mathrm{er}^{\mathrm{b}}$ \\
\hline \multirow[t]{4}{*}{ 1a } & $92 / 8$ & 2 & 0 & - & 97 & $50 / 50$ \\
\hline & $92 / 8$ & 1 & 45 & $50 / 50$ & 44 & $50 / 50$ \\
\hline & $77 / 23$ & 0 & $100^{\mathrm{c}}$ & $75 / 25$ & 0 & - \\
\hline & $77 / 23$ & $-^{\mathrm{d}}$ & $100^{\mathrm{c}}$ & $55 / 45$ & 0 & - \\
\hline \multirow[t]{4}{*}{$1 b$} & $77 / 23$ & 2 & 0 & - & 79 & $50 / 50$ \\
\hline & $77 / 23$ & 1 & 44 & $50 / 50$ & 46 & $50 / 50$ \\
\hline & $73 / 27$ & 0 & $100^{\mathrm{c}}$ & $67 / 33$ & 0 & - \\
\hline & $73 / 27$ & $-^{\mathrm{d}}$ & $100^{\mathrm{c}}$ & $50 / 50$ & 0 & - \\
\hline
\end{tabular}

a Yields are given for isolated (spectroscopically pure) materials.

${ }^{b}$ Enantiomeric ratios (er) were determined as indicated in the text.

c Crude isolate was essentially pure.

${ }^{d}$ Reaction carried out with 2 equiv $\mathrm{MgBr}_{2} \cdot \mathrm{OEt}_{2}$ instead of $\mathrm{MeMgBr}$.

With 2 equiv of Grignard reagent, the reactions proceeded with excellent chemical yield to give the expected tertiary amines $4 \mathbf{a}$ and $\mathbf{4 b}$. With only 1 equiv of the Grignard reagent, these amines were obtained in lower yields and were accompanied by unreacted aminonitrile starting materials. In all cases, products and recovered starting materials were isolated in racemic form. Zero-value optical rotations were observed for crude isolates, suggesting that racemization had occurred during the reaction itself. ${ }^{28}$ Enantiomerically enriched substrates 1a and $\mathbf{1 b}$ were submitted to blank control reactions (no Grignard reagents added) and were recovered with no significant loss of enantiomeric enrichment, suggesting that the Grignard reagent had been responsible for racemization. Enantiomerically enriched substrates 1a and $1 \mathrm{~b}$ were submitted to simulated reaction conditions in the presence of 2 equiv of $\mathrm{MgBr}_{2} \cdot \mathrm{OEt}_{2}$ instead of the Grignard reagent. No amines were obtained, of course, but the recovered starting materials were extensively racemized. We ruled out definitively the (unlikely) possibility that amines $4 \mathbf{a}$ and $4 \mathrm{~b}$ had been racemized after their formation in the reaction mixture: authentic samples of enantiomerically pure amines were prepared from the corresponding commercial primary amines according to Scheme 5. When they were subjected to Bruylants conditions and standard work-up, they were recovered intact and without loss of enantiomeric purity. The enantiomeric enrichments of all samples of amines $\mathbf{4 a}$ and 4 b were determined by ${ }^{1} \mathrm{H}$ NMR spectroscopy in $\mathrm{C}_{6} \mathrm{D}_{6}$ solution in the presence of 1 equiv of $(S)$-mandelic acid as a chiral solvating agent, ${ }^{29}$ which induced complete separation of the methyl doublet signals.

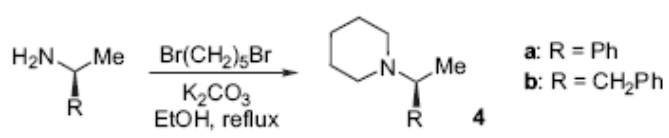

Scheme 5. Yields: $82 \%$ for $4 a, 55 \%$ for $4 b$.

Most preparative applications of the Bruylants reaction are performed using at least 2 equiv of Grignard reagent, and 
indeed we observed only partial conversions when 1 equiv was used. ${ }^{30}$ We performed a further experiment using racemic 1a and 1 equiv of methyl magnesium bromide under typical Bruylants conditions ( $\mathrm{Et}_{2} \mathrm{O}$ solution, $0^{\circ} \mathrm{C}$ to $\mathrm{rt}$ ) then left the stirred mixture at rt for 43 days. After the usual workup, the product comprised a 77/23 mixture $4 \mathbf{a} / \mathbf{1 a}$, obtained with an $83 \%$ overall yield, which corresponds to a $64 \%$ yield of $4 \mathbf{a}$. Clearly, the Bruylants reaction proceeds only very slowly beyond $50 \%$ conversion in the presence of a single equivalent of Grignard reagent.

Collectively, these results suggest the situation which is summarized in Scheme 6. The first Grignard equivalent generates an iminium by cyanide abstraction (step a), and the privileged source of organic nucleophile is a second Grignard equivalent (step b). The significance of the putative magnesium 'ate' complex generated in the first step remains uncertain; in any case, it appears to be a poor source of organic nucleophile. Racemization of the aminonitrile could occur either by return of cyanide nucleophile to the iminium from the magnesium 'ate' species (step c) or by a parallel cyanide elimination-readdition process mediated by $\mathrm{MgX}_{2}$ or some related Lewis acid by-product generated from either of the two Grignard equivalents (step d). Another possible source of $\mathrm{MgX}_{2}$ is the Schlenk equilibrium (step e) $;^{31}$ the $\mathrm{R}_{2} \mathrm{Mg}$ species generated concomitantly might also replace $\mathrm{RMgX}$ in step $\mathrm{b},{ }^{32}$ although this would not change the net inorganic product component mixture $\left[\mathrm{MgX}_{2}+\mathrm{R}^{3} \mathrm{Mg}(\mathrm{CN})\right]$. Intriguingly, the regeneration therefrom of a $\mathrm{RMgX}$ species (step f), which should be available for recycle and thus facilitate complete conversion with only 1 equiv of Grignard, does not appear to operate effectively. In any event, regardless of the relative rates of these processes, they are collectively faster than any conceivable contribution from an intra-complex substitution mechanism for the Bruylants reaction.

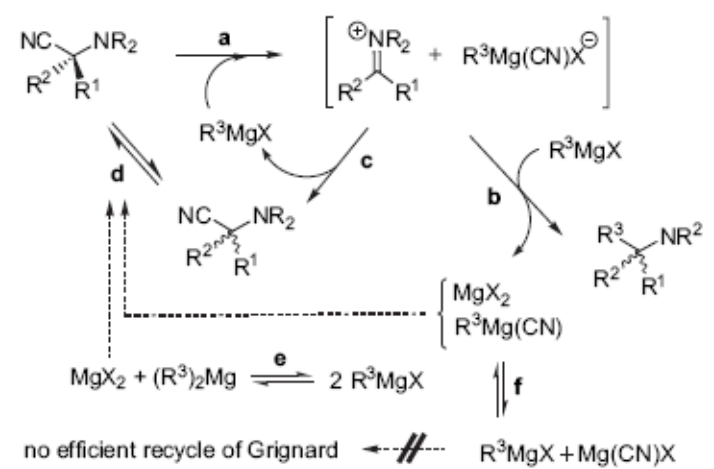

Scheme 6.

\section{Conclusions}

This work confirms the configurational lability of $N, N$ dialkylated aminonitriles in which the amine lone pair is free. Nevertheless, the preparation of single-stereocentre examples in enantiomerically enriched form has been achieved for the first time, and the methods for the determination of enantiomeric purity have been established. The use of these compounds in the Bruylants reaction gives further insight into the mechanism of this transformation and all the evidence obtained is in agreement with the requirement of 2 equiv of Grignard reagent and the intermediacy of a readily formed iminium ion.

\section{Experimental}

\subsection{General methods}

Melting points were determined on a Reichert microscope apparatus. NMR spectra were measured on a Bruker AC-400 spectrometer, operating at $400 \mathrm{MHz}$ for ${ }^{1} \mathrm{H}$ and $100 \mathrm{MHz}$ for ${ }^{13} \mathrm{C}$; chemical shifts $(\delta)$ are reported in parts per million. Infrared spectra were recorded as $\mathrm{KBr}$ pellets (for solid compounds) or neat (for oils) on a Perkin-Elmer 881 spectrometer or a Perkin-Elmer Paragon 500 FTIR spectrometer; only structurally important peaks $(\nu)$ are presented in inverse centimetre. High-resolution mass spectra were recorded in positive electrospray mode on a micro Q-TOF Micromass instrument ( $3000 \mathrm{~V})$ with an internal lock mass $\left(\mathrm{H}_{3} \mathrm{PO}_{4}\right)$ and an external lock mass (Leu-enkephalin). Optical rotations were measured on a Jasco DIP-370 polarimeter. Elemental analyses were carried out by the CNRS Central Microanalytical Laboratory, Lyon. Flash chromatography was carried out on $15 \mathrm{~cm}$ length columns of silica gel $(40-63 \mu \mathrm{m})$. Anhydrous solvents were obtained as follows: ether was distilled from sodium-benzophenone under argon, DMF and dichloromethane were distilled from $\mathrm{CaH}_{2}$ under argon. Ether solutions of methyl magnesium bromide ( $3 \mathrm{M}$ ) were obtained commercially and used as freshly delivered; dilutions in ether were made immediately before reactions were carried out. Procedures for dehydration test reactions reported in Table 1 followed as closely as possible the literature descriptions (see text for references). Compounds $\mathbf{2 a}$ and $\mathbf{2} \mathbf{b}$ were prepared from the corresponding commercial $(R)$-amino acids using literature procedures. ${ }^{25}$ The $(S)$-isomers of compounds $\mathbf{2 c}$ and $\mathbf{2 d}$ were obtained commercially as their hydrochlorides.

\subsection{General procedure for piperidine ring construction}

1,5-Dibromopentane $(5.0 \mathrm{mmol})$ was added to a solution of primary amine substrate $(2.5 \mathrm{mmol})$ in $\mathrm{EtOH}(5 \mathrm{~mL})$ in the presence of potassium carbonate $(13.5 \mathrm{mmol})$. The mixture was refluxed overnight and then cooled to rt. The mixture was filtered and the solids were washed through several aliquots of EtOH; combined filtrate and washings were then evaporated. The residue was purified by flash chromatography $\left(\mathrm{CH}_{2} \mathrm{Cl}_{2} / \mathrm{MeOH} 99 / 1\right)$.

4.2.1. (R)-2-Phenyl-2-(1-piperidinyl)ethanamide (3a). Yield 96\%. Mp $156^{\circ} \mathrm{C}$ (EtOAc); $[\alpha]_{\mathrm{D}}^{25}-27.2(c) 1.0$, $\left.\mathrm{CHCl}_{3}\right)$; IR $\nu 3240,1660 ;{ }^{1} \mathrm{H}$ NMR $\left(\mathrm{CDCl}_{3}\right) \delta 1.16-1.20$ $(\mathrm{m}, 2 \mathrm{H}), 1.38-1.49(\mathrm{~m}, 4 \mathrm{H}), 2.26(\mathrm{~m}, 4 \mathrm{H}), 3.72(\mathrm{~s}, 1 \mathrm{H})$, $6.79(\mathrm{~s}, 1 \mathrm{H}), 7.01(\mathrm{~s}, 1 \mathrm{H}), 7.20-7.28(\mathrm{~m}, 5 \mathrm{H}) ;{ }^{13} \mathrm{C}$ NMR $\left(\mathrm{CDCl}_{3}\right) \delta 24.2\left(\mathrm{CH}_{2}\right), 26.4\left(\mathrm{CH}_{2}\right), 52.7\left(\mathrm{CH}_{2}\right), 76.4(\mathrm{CH})$, $127.9(\mathrm{CH}), 128.3(\mathrm{CH}), 129.0(\mathrm{CH}), 136.5\left(\mathrm{C}_{\mathrm{q}}\right), 175.4$ $\left(\mathrm{C}_{\mathrm{q}}\right)$. HRMS $\mathrm{m} / \mathrm{z}$, calcd for $\mathrm{C}_{13} \mathrm{H}_{19} \mathrm{~N}_{2} \mathrm{O}[\mathrm{MH}]^{+}: 219.1497$; found: 219.1499 .

4.2.2. (R)-3-Phenyl-2-(1-piperidinyl)propanamide (3b). Yield 79\%. Mp $114{ }^{\circ} \mathrm{C}\left(\mathrm{H}_{2} \mathrm{O}\right) ;[\alpha]_{\mathrm{D}}^{25}+45.4\left(c 1.0, \mathrm{CHCl}_{3}\right)$; IR $\nu 3333,1664 ;{ }^{1} \mathrm{H} \mathrm{NMR}\left(\mathrm{CDCl}_{3}\right) \delta 1.28-1.44(\mathrm{~m}, 6 \mathrm{H})$, 
2.33-2.40 (m, 4H), $2.73(\mathrm{dd}, 1 \mathrm{H}, J=6.4$ and $14.0 \mathrm{~Hz}), 3.07$ (dd, $1 \mathrm{H}, J=6.6$ and $14.0 \mathrm{~Hz}), 3.20(\mathrm{t}, 1 \mathrm{H}, J=6.5 \mathrm{~Hz}), 5.57$ (br s, $1 \mathrm{H}), 6.77($ br s, $1 \mathrm{H}), 7.00-7.14(\mathrm{~m}, 5 \mathrm{H}) ;{ }^{13} \mathrm{C}$ NMR $\left(\mathrm{CDCl}_{3}\right)$ o $24.2\left(\mathrm{CH}_{2}\right), 26.7\left(\mathrm{CH}_{2}\right), 32.1\left(\mathrm{CH}_{2}\right), 51.2$ $\left(\mathrm{CH}_{2}\right), 71.2(\mathrm{CH}), 126.0(\mathrm{CH}), 128.3(\mathrm{CH}), 129.2(\mathrm{CH})$, $140.4\left(\mathrm{C}_{\mathrm{q}}\right), 175.4\left(\mathrm{C}_{\mathrm{q}}\right)$. HRMS: $\mathrm{m} / \mathrm{z}$ calcd for $\mathrm{C}_{14} \mathrm{H}_{21} \mathrm{~N}_{2} \mathrm{O}$ $[\mathrm{MH}]^{+}:$233.1654; found: 233.1652 .

4.2.3. (S)-2-(1-Piperidinyl)propanamide (3c). Yield $62 \%$. Mp $112^{\circ} \mathrm{C}$ (hexane); $[\alpha]_{\mathrm{D}}^{24}+22.2\left(c 1.56, \mathrm{CHCl}_{3}\right)$; IR $\nu$ $3314,3088,1666 ;{ }^{1} \mathrm{H}$ NMR $\left(\mathrm{CDCl}_{3}\right) \delta 1.17(\mathrm{~d}, 3 \mathrm{H}$, $J=7.2 \mathrm{~Hz}), 1.41(\mathrm{~m}, 2 \mathrm{H}), 1.51(\mathrm{~m}, 4 \mathrm{H}), 2.38(\mathrm{~m}, 2 \mathrm{H}), 2.47$ $(\mathrm{m}, 2 \mathrm{H}), 3.01(\mathrm{q}, 1 \mathrm{H}, J=6.8 \mathrm{~Hz}), 6.18(\mathrm{~s}, 1 \mathrm{H}), 7.18(\mathrm{~s}$, 1H). ${ }^{13} \mathrm{C} \mathrm{NMR}\left(\mathrm{CDCl}_{3}\right) \delta 10.7\left(\mathrm{CH}_{3}\right), 24.1\left(\mathrm{CH}_{2}\right), 26.4$ $\left(\mathrm{CH}_{2}\right), 51.0\left(\mathrm{CH}_{2}\right), 64.4(\mathrm{CH}), 177.6\left(\mathrm{C}_{\mathrm{q}}\right)$. HRMS m/z calcd for $\mathrm{C}_{8} \mathrm{H}_{17} \mathrm{~N}_{2} \mathrm{O}[\mathrm{MH}]^{+}$: 157.1341; found: 157.1336. Anal. Calcd for $\mathrm{C}_{8} \mathrm{H}_{16} \mathrm{~N}_{2} \mathrm{O}: \mathrm{C}, 61.51 ; \mathrm{H}, 10.32 ; \mathrm{N}, 17.93$. Found: C, 61.46; H, 10.31; N, 17.82 .

4.2.4. (S)-3-Methyl-2-(1-piperidinyl)butanamide (3d). Yield $56 \%$. Mp $103{ }^{\circ} \mathrm{C}$ (hexane); $[\alpha]_{\mathrm{D}}^{21}-9.7$ (c 1.125 , $\left.\mathrm{CHCl}_{3}\right)$; IR $\nu 3372,3186,1661 ;{ }^{1} \mathrm{H}$ NMR $\left(\mathrm{CDCl}_{3}\right) \delta 0.91$ $(\mathrm{d}, 3 \mathrm{H}, J=6.8 \mathrm{~Hz}), 1.01(\mathrm{~d}, 3 \mathrm{H}, J=6.8 \mathrm{~Hz}), 1.46(\mathrm{~m}, 2 \mathrm{H})$, $1.56(\mathrm{~m}, 4 \mathrm{H}), 2.14(\mathrm{o}, 1 \mathrm{H}, J=6.8 \mathrm{~Hz}), 2.47(\mathrm{~m}, 4 \mathrm{H}), 2.54$ $(\mathrm{d}, 1 \mathrm{H}, J=6.4 \mathrm{~Hz}) ;{ }^{13} \mathrm{C}$ NMR $\left(\mathrm{CDCl}_{3}\right) \delta 17.7\left(\mathrm{CH}_{3}\right), 20.0$ $\left(\mathrm{CH}_{3}\right), 24.6\left(\mathrm{CH}_{2}\right), 26.2(\mathrm{CH}), 26.4\left(\mathrm{CH}_{2}\right), 51.7\left(\mathrm{CH}_{2}\right)$, $75.84(\mathrm{CH}), 174.3\left(\mathrm{C}_{\mathrm{q}}\right)$. HRMS $\mathrm{m} / \mathrm{z}$ calcd for $\mathrm{C}_{10} \mathrm{H}_{21} \mathrm{~N}_{2} \mathrm{O}$ $[\mathrm{MH}]^{+}$: 185.1654 ; found: 185.1667. Anal. Calcd for $\mathrm{C}_{10} \mathrm{H}_{20} \mathrm{~N}_{2} \mathrm{O}$ : C, 65.18; H, 10.94; N, 15.20. Found: C, $65.16 ; \mathrm{H}, 10.97 ; \mathrm{N}, 15.25$.

4.2.5. (S)-1-(1-Phenylethyl)piperidine (4a). Yield 82\%. Oil, bp $110-116^{\circ} \mathrm{C}(4 \mathrm{mmHg}) ;[\alpha]_{\mathrm{D}}^{25}-26.0$ (c 1.2 , $\left.\mathrm{CHCl}_{3}\right)$; IR $\nu 3040 ;{ }^{1} \mathrm{H}$ NMR $\left(\mathrm{CDCl}_{3}\right) \delta 1.32-1.38(\mathrm{~m}$, $2 \mathrm{H}), 1.44(\mathrm{~d}, 3 \mathrm{H}, J=6.8 \mathrm{~Hz}), 1.56-1.66(\mathrm{~m}, 4 \mathrm{H}), 2.43$ $2.49(\mathrm{~m}, 4 \mathrm{H}), 3.54(\mathrm{q}, 1 \mathrm{H}, J=6.8 \mathrm{~Hz}), 7.11-7.23(\mathrm{~m}, 5 \mathrm{H})$; ${ }^{13} \mathrm{C} \mathrm{NMR}\left(\mathrm{CDCl}_{3}\right) \delta 19.4\left(\mathrm{CH}_{3}\right), 24.6\left(\mathrm{CH}_{2}\right), 26.3\left(\mathrm{CH}_{2}\right)$, $51.5\left(\mathrm{CH}_{2}\right), 65.2(\mathrm{CH}), 126.6(\mathrm{CH}), 127.7(\mathrm{CH}), 128.0$ $(\mathrm{CH}), 144.0\left(\mathrm{C}_{\mathrm{q}}\right)$. HRMS $\mathrm{m} / \mathrm{z}$ calcd for $\mathrm{C}_{13} \mathrm{H}_{20} \mathrm{~N}[\mathrm{MH}]^{+}$: 190.1596; found: 190.1596 .

4.2.6. (S)-1-(1-Methyl-2-phenylethyl)piperidine (4b). Yield $55 \%$. Oil, bp $120-128{ }^{\circ} \mathrm{C}(4 \mathrm{mmHg}) ;[\alpha]_{\mathrm{D}}^{25}+15.5(c$ $\left.1.1, \mathrm{CHCl}_{3}\right)$; IR $\nu 3040 ;{ }^{1} \mathrm{H} \mathrm{NMR}\left(\mathrm{CDCl}_{3}\right) \delta 0.90(\mathrm{~d}, 3 \mathrm{H}$, $J=6.6 \mathrm{~Hz}), 1.39-1.45(\mathrm{~m}, 2 \mathrm{H}), 1.63-1.69(\mathrm{~m}, 4 \mathrm{H}), 2.35$ (dd, $1 \mathrm{H}, J=12.8$ and $10.4 \mathrm{~Hz}), 2.60-2.63(\mathrm{~m}, 4 \mathrm{H}), 2.84$ $2.92(\mathrm{~m}, 1 \mathrm{H}), 3.12(\mathrm{dd}, 1 \mathrm{H} J=12.8$ and $3.6 \mathrm{~Hz}), 7.08-7.29$ $(\mathrm{m}, 5 \mathrm{H}) ;{ }^{13} \mathrm{C}$ NMR $\left(\mathrm{CDCl}_{3}\right) \delta 13.8\left(\mathrm{CH}_{3}\right), 24.3\left(\mathrm{CH}_{2}\right)$, $25.5\left(\mathrm{CH}_{2}\right), 38.8\left(\mathrm{CH}_{2}\right), 49.6\left(\mathrm{CH}_{2}\right), 62.5(\mathrm{CH}), 126.1$ $(\mathrm{CH}), 128.3(\mathrm{CH}), 129.2(\mathrm{CH}), 139.7\left(\mathrm{C}_{\mathrm{q}}\right)$. HRMS $\mathrm{m} / \mathrm{z}$ calcd for $\mathrm{C}_{14} \mathrm{H}_{22} \mathrm{~N}[\mathrm{MH}]^{+}:$204.1752; found: 204.1763 .

\subsection{Strecker synthesis of reference racemic aminonitriles}

Piperidine $(20 \mathrm{mmol})$ was treated with exactly 1 equiv of $3.5 \mathrm{M}$ hydrochloric acid solution and the appropriate aldehyde $(20 \mathrm{mmol})$ was then added. A solution of $\mathrm{KCN}$ $(23 \mathrm{mmol})$ in a minimum of water $(c 1 \mathrm{~mL})$ was added dropwise and then the mixture was stirred at $\mathrm{rt}[2 \mathrm{~h}$ for $( \pm)$-1a and $( \pm)-1 \mathrm{c}, 16 \mathrm{~h}$ for $( \pm)-1 \mathrm{~b}$ and $48 \mathrm{~h}$ for $( \pm)-1 \mathrm{~d}]$. Dichloromethane $(5 \mathrm{~mL})$ was added and the organic phase was collected, dried over $\mathrm{MgSO}_{4}$ and then evaporated. The residue was purified by crystallization $[( \pm)-1 \mathbf{a}]$ or by flash chromatography $\left[\mathrm{CH}_{2} \mathrm{Cl}_{2} /\right.$ cyclohexane $50 / 50$ for $( \pm)$-1b and ( \pm )-1d, $\mathrm{CH}_{2} \mathrm{Cl}_{2} / \mathrm{EtOAc} 99 / 1$ for $\left.( \pm)-1 \mathrm{c}\right]$.

4.3.1. ( \pm )-2-Phenyl-2-(1-piperidinyl)ethanenitrile (1a). Yield 32\%. Mp $60{ }^{\circ} \mathrm{C}(\mathrm{MeOH})$; IR $\nu 2220 ;{ }^{1} \mathrm{H}$ NMR $\left(\mathrm{CDCl}_{3}\right) \delta 1.49-1.70(\mathrm{~m}, 6 \mathrm{H}), 2.53-2.58(\mathrm{~m}, 4 \mathrm{H}), 4.84(\mathrm{~s}$, $1 \mathrm{H}), 7.28-7.45(\mathrm{~m}, 5 \mathrm{H}) ;{ }^{13} \mathrm{C}$ NMR $\left(\mathrm{CDCl}_{3}\right) \delta 23.7\left(\mathrm{CH}_{2}\right)$, $25.8\left(\mathrm{CH}_{2}\right), 50.9\left(\mathrm{CH}_{2}\right), 63.0(\mathrm{CH}), 115.6\left(\mathrm{C}_{\mathrm{q}}\right), 127.8$ $(\mathrm{CH}), 128.2(\mathrm{CH}), 128.7(\mathrm{CH}), 133.5\left(\mathrm{C}_{\mathrm{q}}\right)$. HRMS $\mathrm{m} / z$ calcd for $\mathrm{C}_{13} \mathrm{H}_{17} \mathrm{~N}_{2}[\mathrm{MH}]^{+}$: 201.1392; found: 201.1397. Anal. Calcd for $\mathrm{C}_{13} \mathrm{H}_{16} \mathrm{~N}_{2}$ : C, 77.96; H, 8.05; N, 13.99. Found: C, 77.35; H, 8.11; N, 13.88.

4.3.2. ( \pm )-3-Phenyl-2-(1-piperidinyl)propanenitrile (1b). Yield $27 \%$. Mp $30{ }^{\circ} \mathrm{C}$; IR $\nu 2222 ;{ }^{1} \mathrm{H}$ NMR $\left(\mathrm{CDCl}_{3}\right)$ $\delta$ 1.44-1.62 (m, 6H), 2.36-2.41 (m, 2H), 2.62-2.67 (m, $2 \mathrm{H}), 2.95-2.98(\mathrm{~m}, 2 \mathrm{H}), 3.55(\mathrm{dd}, 1 \mathrm{H}, J=8.0$ and $8.6 \mathrm{~Hz})$, $7.19-7.28(\mathrm{~m}, 5 \mathrm{H}) ;{ }^{13} \mathrm{C} \mathrm{NMR}\left(\mathrm{CDCl}_{3}\right) \delta 24.0\left(\mathrm{CH}_{2}\right), 25.8$ $\left(\mathrm{CH}_{2}\right), 37.7\left(\mathrm{CH}_{2}\right), 51.1\left(\mathrm{CH}_{2}\right), 61.3(\mathrm{CH}), 116.7\left(\mathrm{C}_{\mathrm{q}}\right)$, $127.3(\mathrm{CH}), 128.7(\mathrm{CH}), 129.2(\mathrm{CH}), 136.2\left(\mathrm{C}_{q}\right)$. HRMS $\mathrm{m} / \mathrm{z}$ calcd for $\mathrm{C}_{14} \mathrm{H}_{19} \mathrm{~N}_{2}[\mathrm{MH}]^{+}:$215.1548; found: 215.1555. Anal. Calcd for $\mathrm{C}_{14} \mathrm{H}_{18} \mathrm{~N}_{2}$ : C, 78.46; H, 8.47; N, 13.07. Found: $\mathrm{C}, 78.14 ; \mathrm{H}, 8.56 ; \mathrm{N}, 12.49$.

4.3.3. ( \pm )-2-(1-Piperidinyl)propanenitrile (1c). Yield $21 \%$. Oil, bp $60{ }^{\circ} \mathrm{C}(0.6 \mathrm{mmHg})$; IR $\nu 2223 ;{ }^{1} \mathrm{H}$ NMR $\left(\mathrm{CDCl}_{3}\right) \delta 1.43(\mathrm{~d}, 3 \mathrm{H}, J=7.2 \mathrm{~Hz}), 1.45(\mathrm{~m}, 2 \mathrm{H}), 1.58(\mathrm{~m}$, $4 \mathrm{H}), 2.36(\mathrm{~m}, 2 \mathrm{H}), 2.61(\mathrm{~m}, 2 \mathrm{H}), 3.59(\mathrm{q}, 1 \mathrm{H}, J=7.2 \mathrm{~Hz})$; ${ }^{13} \mathrm{C} \mathrm{NMR}\left(\mathrm{CDCl}_{3}\right) \delta 17.2\left(\mathrm{CH}_{3}\right), 24.1\left(\mathrm{CH}_{2}\right), 25.8\left(\mathrm{CH}_{2}\right)$, $50.7\left(\mathrm{CH}_{2}\right), 53.1(\mathrm{CH}), 117.7\left(\mathrm{C}_{\mathrm{q}}\right)$. HRMS m/z calcd for $\mathrm{C}_{8} \mathrm{H}_{15} \mathrm{~N}_{2}[\mathrm{MH}]^{+}: 139.1235$; found: 139.1240 .

4.3.4. ( \pm )-3-Methyl-2-(1-piperidinyl)butanenitrile (1d). Yield $68 \%$. Mp $54{ }^{\circ} \mathrm{C}$ (sublimation); IR $\nu$ 2220; ${ }^{1} \mathrm{H}$ NMR $\left(\mathrm{CDCl}_{3}\right) \delta 0.95(\mathrm{~d}, 3 \mathrm{H}, J=6.4 \mathrm{~Hz}), 1.07(\mathrm{~d}, 3 \mathrm{H}, J=6.8 \mathrm{~Hz})$, $1.44(\mathrm{~m}, 2 \mathrm{H}), 1.57(\mathrm{~m}, 4 \mathrm{H}), 1.96(\mathrm{~m}, 1 \mathrm{H}), 2.31(\mathrm{~m}, 2 \mathrm{H})$, $2.55(\mathrm{~m}, 2 \mathrm{H}), 2.91(\mathrm{~d}, 1 \mathrm{H} J=11.2 \mathrm{~Hz}) ;{ }^{13} \mathrm{C} \mathrm{NMR}\left(\mathrm{CDCl}_{3}\right)$ $\delta 19.1\left(\mathrm{CH}_{3}\right), 20.2\left(\mathrm{CH}_{3}\right), 24.1\left(\mathrm{CH}_{2}\right), 25.8\left(\mathrm{CH}_{2}\right), 28.8$ $(\mathrm{CH}), 51.0\left(\mathrm{CH}_{2}\right), 66.1(\mathrm{CH}), 117.0\left(\mathrm{C}_{\mathrm{q}}\right)$. HRMS $\mathrm{m} / \mathrm{z}$ calcd for $\mathrm{C}_{10} \mathrm{H}_{19} \mathrm{~N}_{2}[\mathrm{MH}]^{+}$: 167.1548; found: 167.1549. Anal. Calcd for $\mathrm{C}_{10} \mathrm{H}_{18} \mathrm{~N}_{2}$ : C, 72.24; H, 10.91; N, 16.85. Found: C, $71.95 ; \mathrm{H}, 10.90 ; \mathrm{N}, 16.91$.

\subsection{Dehydration procedure using Burgess' salt}

Under an argon atmosphere, a solution of the carboxamide $(0.46 \mathrm{mmol})$ in anhydrous dichloromethane $(2.5 \mathrm{~mL})$ was stirred at rt while Burgess' salt was added in small portions over $2 \mathrm{~h}$. The reaction mixture was then passed through a flash chromatography column without prior evaporation of the solvent [eluent $\mathrm{CH}_{2} \mathrm{Cl}_{2}$ /cyclohexane 50/50 for (+)1a, (+)-1b and (-)-1d; $\mathrm{CH}_{2} \mathrm{Cl}_{2} /$ EtOAc $99 / 1$ for (-)-1c]. Appropriate fractions were pooled and evaporated to give the required product, which was not further purified.

4.4.1. (R)-2-Phenyl-2-(1-piperidinyl)ethanenitrile (1a). Yield $78 \%$. Yellow solid; $[\alpha]_{\mathrm{D}}^{22}+44\left(\right.$ c $\left.1.0, \mathrm{CHCl}_{3}\right)$; er (by chiral HPLC): $92 / 8 ;{ }^{1} \mathrm{H}$ and ${ }^{13} \mathrm{C}$ NMR: as for racemic sample.

4.4.2. (R)-3-Phenyl-2-(1-piperidinyl)propanenitrile (1b). Yield $71 \%$. Yellow solid; $[\alpha]_{\mathrm{D}}^{22}+6.5\left(c 1.0, \mathrm{CHCl}_{3}\right)$; er (by 
NMR with chiral resolving agent): $62 / 38 ;{ }^{1} \mathrm{H}$ and ${ }^{13} \mathrm{C}$ NMR: as for racemic sample.

4.4.3. (S)-2-(1-Piperidinyl)propanenitrile (1c). Yield 80\%. Yellow liquid; $[\alpha]_{\mathrm{D}}^{21}-24.0\left(c 1.105, \mathrm{CHCl}_{3}\right)$; er (by NMR with chiral resolving agent): $53 / 47 ;{ }^{1} \mathrm{H}$ and ${ }^{13} \mathrm{C}$ NMR: as for racemic sample.

4.4.4. (S)-3-Methyl-2-(1-piperidinyl)butanenitrile (1d). Yield $87 \%$. White solid; $[\alpha]_{\mathrm{D}}^{25}-28\left(c 1.18, \mathrm{CHCl}_{3}\right)$; er (by NMR with chiral resolving agent): $81 / 19 ;{ }^{1} \mathrm{H}$ and

${ }^{13}$ C NMR: as for racemic sample.

\subsection{Dehydration procedure using TFAA/Et ${ }_{3} \mathrm{~N}$}

Under an argon atmosphere, carboxamide $(1.12 \mathrm{mmol})$ was dissolved in anhydrous dichloromethane $(45 \mathrm{~mL})$ and then triethylamine $(0.34 \mathrm{~mL}, 2.44 \mathrm{mmol})$ was added dropwise. The mixture was cooled at $0{ }^{\circ} \mathrm{C}$ and then trifluoroacetic anhydride $(0.17 \mathrm{~mL}, 1.20 \mathrm{mmol})$ was added dropwise. The mixture was stirred and allowed to return to $\mathrm{rt}$ over $3 \mathrm{~h}$ and then was washed with a saturated $\mathrm{NaHCO}_{3}$ solution $(2 \times 25 \mathrm{~mL})$. The organic phase was dried over $\mathrm{MgSO}_{4}$ and evaporated under reduced pressure to leave the product 1a-d (see Table 2).

\subsection{Dehydration procedure using $\mathrm{CyuCl} / \mathrm{DMF}$}

Under an argon atmosphere, carboxamide $(0.95 \mathrm{mmol})$ was dissolved in anhydrous DMF $(3 \mathrm{~mL})$. The solution was cooled at $0{ }^{\circ} \mathrm{C}$ and cyanuric chloride $(0.118 \mathrm{~g}, 0.64 \mathrm{mmol})$ was added in one portion. The mixture was allowed to return to $\mathrm{rt}$ over $8 \mathrm{~h}$ and then was quenched by the addition of distilled water $(5 \mathrm{~mL})$. The aqueous phase was extracted with ethyl acetate $(10 \mathrm{~mL})$. The organic phase was washed with water, dried over $\mathrm{MgSO}_{4}$ and evaporated under reduced pressure to leave the products 1a-d (see Table 2).

\subsection{Bruylants reactions}

Under an argon atmosphere, a solution of methyl magnesium bromide (variable amount; see Table 2) in anhydrous ether $(8 \mathrm{~mL})$ was cooled at $0{ }^{\circ} \mathrm{C}$ while a solution of aminonitrile $1(4.00 \mathrm{mmol})$ in anhydrous ether was added dropwise. The mixture was stirred and allowed to return to $\mathrm{rt}$ overnight. A saturated solution of $\mathrm{NH}_{4} \mathrm{Cl}(10 \mathrm{~mL})$ was added and the ether phase was retained. The aqueous phase was extracted with dichloromethane $(3 \times 10 \mathrm{~mL})$. Combined ether and dichloromethane phases were dried over $\mathrm{MgSO}_{4}$ and evaporated. The crude product was checked by NMR and its optical rotation was measured. Products were then separated and purified by flash chromatography $\left(\mathrm{CH}_{2} \mathrm{Cl}_{2} /\right.$ cyclohexane 50/50). See Table 3 for results. Tertiary amines were obtained as follows.

4.7.1. ( \pm )-1-(1-Phenyl-1-ethyl)piperidine (4a). $[\alpha]_{D}^{22} 0(c$ $1.0, \mathrm{CHCl}_{3}$ ); er (by NMR with chiral resolving agent): 50 / 50; ${ }^{1} \mathrm{H}$ and ${ }^{13} \mathrm{C}$ NMR: as for $(S)$-enantiomer.

4.7.2. ( \pm )-1-(1-Methyl-2-phenylmethyl)piperidine (4b). $[\alpha]_{\mathrm{D}}^{22} 0\left(c 1.0, \mathrm{CHCl}_{3}\right)$; er (by NMR with chiral resolving agent): $50 / 50 ;{ }^{1} \mathrm{H}$ and ${ }^{13} \mathrm{C}$ NMR: as for $(S)$-enantiomer.

\subsection{Determination of enantiomeric ratios}

4.8.1. HPLC analysis. HPLC analysis was performed using a Waters 501 apparatus equipped with a Waters 484 detector and a Chiracel OD column $(4.6 \mathrm{~mm} \times 250 \mathrm{~mm})$ under the following conditions: hexane/isopropanol $995 / 5$ as mobile phase, rt, $\lambda=254 \mathrm{~nm}$, flow rate $=0.5 \mathrm{~mL} / \mathrm{min}$. Retention times: $(S)-1 \mathbf{a}, 13.21 \mathrm{~min}$; $(R)-\mathbf{1 a}, 14.73 \mathrm{~min}$.

4.8.2. Chiral resolving agents. A solution of test substance $(15-35 \mu \mathrm{mol})$ in the appropriate solvent $(0.5 \mathrm{~mL})$ was treated with: (A) 7-8 equiv of (S)-2,2,2-trifluoro-1-(9anthryl)ethanol, or (B) 1 equiv of $(R)$-Mosher acid, or (C) 1 equiv of $(S)$-mandelic acid. The ${ }^{1} \mathrm{H}$ NMR spectrum was recorded immediately. Diagnostic signals are indicated.

Compound 1b: $\mathrm{CDCl}_{3}$ (A) $\delta: 3.54 \mathrm{ppm}$ for $(R)-\mathbf{1 b}$ and $3.59 \mathrm{ppm}$ for $(S)-\mathbf{1 b}$.

Compound 1c: $\mathrm{CDCl}_{3}$ (A) $\delta: 2.10 \mathrm{ppm}$ for $(R)-1 \mathrm{c}$ and $2.22 \mathrm{ppm}$ for $(S)-1 \mathrm{c}$.

Compound 1d: $\mathrm{C}_{6} \mathrm{D}_{6}$ (B) $\delta: 2.93 \mathrm{ppm}$ for $(R)-\mathbf{1 d}$ and $2.98 \mathrm{ppm}$ for $(S)-\mathbf{1 d}$.

Compound 4a: $\mathrm{C}_{6} \mathrm{D}_{6}(\mathrm{C}) \quad \delta: 1.33 \mathrm{ppm}$ for $(R)-\mathbf{4 a}$ and $1.38 \mathrm{ppm}$ for $(S) \mathbf{4 a}$.

Compound 4b: $\mathrm{C}_{6} \mathrm{D}_{6}(\mathrm{C}) \delta: 0.79 \mathrm{ppm}$ for $(R)-\mathbf{4 b}$ and $0.82 \mathrm{ppm}$ for $(S)-\mathbf{4 b}$.

\section{Acknowledgements}

We are grateful to Pfizer Global Research for research funding and the award of a Ph.D grant (to V.B.-D.); in this context, we warmly thank F. Vergne for his support and interest in our work. We also acknowledge B. Legeret for HRMS measurements and E. Conchon and E. Sagot for help with some reactions.

\section{References and notes}

1. (a) Bruylants, P. Bull. Soc. Chim. Belg. 1924, 33, 467-478; (b) Bruylants, P. Bull. Soc. Chim. Belg. 1926, 35, 139-154.

2. For recent examples of the use of the Bruylants reaction and its variations in synthesis, see: (a) Prashad, M.; Liu, Y.; Har, D.; Repič, O.; Blacklock, T. J. Tetrahedron Lett. 2005, 46, 54555458; (b) Ting, P. C.; Umland, S. P.; Aslanian, R.; Cao, J.; Garlisi, C. G.; Huang, Y.; Jakway, J.; Liu, Z.; Shah, H.; Tian, F.; Wan, Y.; Shih, N.-Y. Bioorg. Med. Chem. Lett. 2005, 15, 3020-3023; (c) Reimann, E.; Ettmayr, C. Monatsh. Chem. 2004, 135, 1289-1295; (d) Reimann, E.; Ettmayr, C. Monatsh. Chem. 2004, 135, 1143-1155; (e) Reimann, E.; Ettmayr, C.; Polborn, K. Monatsh. Chem. 2004, 135, 557579; (f) Bernardi, L.; Bonini, B. F.; Capitò, E.; Dessole, G.; Fochi, M.; Comes-Franchini, M.; Ricci, A. Synlett 2003, 1778-1782; (g) Amos, D. T.; Renslo, A. R.; Danheiser, R. L. J. Am. Chem. Soc. 2003, 125, 4970-4971; (h) Palani, A.; Shapiro, S.; Josien, H.; Bara, T.; Clader, J. W.; Greenlee, W. J.; Cox, K.; Strizki, J. M.; Baroudy, B. M. J. Med. Chem. 2002, 45, 3143-3160; (i) Tagat, J. R.; Steensma, R. W.; 
McCombie, S. W.; Nazareno, D. V.; Lin, S.-I.; Neustadt, B. R.; Cox, K.; Xu, S.; Wojcik, L.; Murray, M. G.; Vantuno, N.; Baroudy, B. M.; Striski, J. M. J. Med. Chem. 2001, 44, 33433346; (j) Enders, D.; Thiebes, C. Synlett 2000, 1745-1748; (k) Agami, C.; Couty, F.; Evano, G. Org. Lett. 2000, 2, 20852088; (1) Suau, R.; Nájera, F.; Rico, R. Tetrahedron 2000, 56, 9713-9723; (m) Schneider, C.; Börner, C. Synlett 1998, 652654; (n) Bonjoch, J.; Fernàndez, J.-C.; Terricabras, D.; Valls, N. Tetrahedron 1997, 53, 9407-9414; (o) Salerno, A.; Ceriani, V.; Perillo, I. A. J. Heterocycl. Chem. 1997, 34, 709716; (p) Al-Deeb, O. A. Sci. Pharm. 1997, 65, 253-270; (q) Hammon, J.; Vignon, J.; Kamenka, J. M. Eur. J. Med. Chem. 1996, 31, 489-495; (r) Yue, C.; Gauthier, I.; Royer, J.; Husson, H.-P. J. Org. Chem. 1996, 61, 4949-4954.

3. (a) Enders, D.; Shilvock, J. P. Chem. Soc. Rev. 2000, 29, 359 373; (b) Husson, H.-P.; Royer, J. Chem. Soc. Rev. 1999, 28, 383-394; (c) Shafran, Y. M.; Bakulev, V. A.; Mokrushin, V. S. Russ. Chem. Rev. 1989, 58, 148-162; (d) Maigrot, N.; Mazaleyrat, J.-P.; Welvart, Z. J. Chem. Soc., Chem. Commun. $1984,40-41$.

4. Guerrier, L.; Royer, J.; Grierson, D. S.; Husson, H.-P. J. Am. Chem. Soc. 1983, 105, 7754-7755.

5. Aitken, D. J.; Beaufort, V.; Chalard, P.; Cladière, J.-L.; Dufour, M.; Pereira, E.; Théry, V. Tetrahedron 2002, 58, 5933-5940.

6. Bull, S. D.; Correia, L. M. A. R. B.; Davies, S. G. J. Chem. Soc., Perkin Trans. 1 1998, 2231-2233.

7. This is in marked contrast with the vast number of examples of non-racemic aminonitriles which contain two or more stereogenic centres. For some illustrations, see Ref. 3.

8. Nazabadioko, S.; Pérez, R. J.; Brieva, R.; Gotor, V. Tetrahedron: Asymmetry 1998, 9, 1597-1604.

9. (a) Hylton, T. A.; Shenton, F. L. U.S. Patent 4,072,698, 1978 ; Chem. Abstr. 1978, 88, 152276; (b) Matthews, G. French Patent 2141354, 1973; Chem. Abstr. 1973, 79, 42210.

10. López-Serrano, P.; Jongejan, J. A.; van Rantwijk, F.; Sheldon, R. A. Tetrahedron: Asymmetry 2001, 12, 219-228.

11. Sonke, T.; Kaptein, B.; Wagner, A. F. V.; Quaedflieg, P. J. L. M.; Schultz, S.; Ernste, S.; Schepers, A.; Mommers, J. H. M.; Broxterman, Q. B. J. Mol. Catal. B: Enzym. 2004, 29, 265-277.

12. Effenberger, F.; Kremser, A.; Stelzer, U. Tetrahedron: Asymmetry 1996, 7, 607-618.

13. For reviews, see: (a) Spino, C. Angew. Chem., Int. Ed. 2004, 43, 1764-1766; (b) Gröger, H. Chem. Rev. 2003, 103, 2795-2827; (c) Yet, L. Organic Synthesis Highlights V; Schmalz, H.-G., Wirth, T., Eds.; Wiley-VCH: Weinheim, 2003; pp 187-193; (d) Yet, L. Angew. Chem., Int. Ed. 2001, 40, 875-877.

14. An example of a one-pot three-component enantioselective Strecker reaction has been described, but the amine involved is an aniline, which therefore gives an $\mathrm{N}$-monosubstituted aminonitrile, see: Ishitani, H.; Komiyama, S.; Hasegawa, Y.; Kobayashi, S. J. Am. Chem. Soc. 2000, 122, 762-766.

15. (a) Kawashiro, K.; Yoshida, H.; Morimoto, S. Bull. Chem. Soc. Jpn. 1977, 50, 2956-2960; (b) Morley, J. S. J. Chem. Soc. C 1969, 809-813; (c) Woolley, D. W.; Hershey, J. W. B.; Jodlowski, H. A. J. Org. Chem. 1963, 28, 2012-2015.

16. (a) Yamada, T.; Suegane, K.; Kuwata, S.; Watanabe, H. Bull. Chem. Soc. Jpn. 1977, 50, 1088-1093; (b) Hirotsu, Y.; Shiba, T.; Kaneko, T. Bull. Chem. Soc. Jpn. 1967, 40, 2945-2949.
17. Thompson, S. A.; Andrews, P. R.; Hanzlik, R. P. J. Med. Chem. 1986, 29, 104-111.

18. Bose, D. S.; Jayalakshmi, B. Synthesis 1999, 64-65.

19. (a) Bose, D. S.; Jayalakshmi, B.; Goud, P. R. Synthesis 1999, 1724-1726; (b) Bose, D. S.; Jayalakshmi, B. J. Org. Chem. 1999, 64, 1713-1714.

20. (a) Bose, D. S.; Narsaiah, A. V. Synthesis 2001, 373-375; (b) Bose, D. S.; Kumar, K. K. Synth. Commun. 2000, 30, 30473052; (c) Bose, D. S.; Sunder, K. S. Synth. Commun. 1999, $29,4235-4239$.

21. (a) Demko, Z. P.; Sharpless, K. B. Org. Lett. 2002, 4, $2525-$ 2527: (b) Maetz, P.; Rodriguez, M. Tetrahedron Lett. 1997, 38, 4221-4222; (c) Spero, D. M.; Kapadia, S. R. J. Org. Chem. 1996, 61, 7398-7401.

22. Claremon, D. A.; Phillips, B. T. Tetrahedron Lett. 1988, 29, $2155-2158$.

23. Cai, L.; Han, Y.; Ren, S.; Huang, L. Tetrahedron 2000, 56, $8253-8262$.

24 . In interesting related work, tetrahydro- $\beta$-carboline derived carboxamides with two stereogenic centres have been dehydrated using $\mathrm{POCl}_{3}$ or TFAA, apparently with total diastereoisomeric control, see: (a) Waldmann, H.; Schmidt, G.; Jansen, M.; Geb, J. Tetrahedron 1994, 50, 11865-11884; (b) Yamada, S.-i.; Akimoto, H. Tetrahedron Lett. 1969, 3105-3108.

25. Compounds 2 are available commercially, although they can be expensive. As an alternative they can be prepared from the corresponding aminoacids using standard operations, see: (a) Lagriffoul, P.-H.; Tadros, Z; Taillades, J.; Commeyras, A. J. Chem. Soc., Perkin Trans. 2 1992, 1279-1285; (b) Hsu, F.-L.; Hamada, A.; Booher, M. E.; Fuder, H.; Patil, P. N.; Miller, D. D. J. Med. Chem. 1980, 23, 1232-1235.

26. (a) Beaufour, M.; Merelli, B.; Menguy, L.; Cherton, J.-C. Chirality 2003, 15, 382-390; (b) Pirkle, W. H.; Sikkenga, D. L.; Pavlin, M. S. J. Org. Chem. 1977, 42, 384-387.

27. (a) Navrátilová, H. Chirality 2001, 13, 731-735; (b) Villani, F. J., Jr.; Costanzo, M. J.; Inners, R. R.; Mutter, M. S.; McClure, D. E. J. Org. Chem. 1986, 51, 3715-3718.

28. Occasionally, the crude isolate had a small but non-zero optical rotation. This is explained by the presence of traces of the chiral carboxamide 3 , carried through with the aminonitrile 1 ; the carboxamides are apparently not transformed in the Bruylants conditions. In such cases, the presence of the carboxamide was confirmed by GLC analysis of the crude Bruylants reaction product mixture.

29. Benson, S. C.; Cai, P.; Colon, M.; Haiza, M. A.; Tokles, M.; Snyder, J. K. J. Org. Chem. 1988, 53, 5335-5341.

30. We are aware of only one description of a series of Bruylants reactions which appear to have been carried out using 1.1 equiv of Grignard reagents. The substrates were $\alpha$-secondary allylic $\alpha$-aminonitriles and reported yields of amines averaged around $60 \%$, see: Ahlbrecht, H.; Dollinger, H. Synthesis 1985, 743-748.

31. (a) Schlenk, W.; Schlenk, W., Jr. Chem. Ber. 1929, 62, 920924; (b) Lindsell, W. E. Comprehensive Organometallic Chemistry II; Wilkinson, G., Stone, F. G. A., Abel, E. W. Eds.; Pergamon: Oxford, 1995; Vol. 1, pp 57-127.

32. Chauvière, G.; Tchoubar, B.; Welvart, Z. Bull. Soc. Chim. Fr $1963,1428-1433$. 